Article

\title{
Awareness, Knowledge, and Interest about Prebiotics-A Study among Romanian Consumers
}

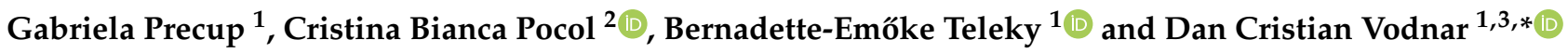 \\ 1 Faculty of Food Science and Technology, University of Agricultural Sciences and Veterinary Medicine, \\ 400372 Cluj-Napoca, Romania; gabriela.precup@usamvcluj.ro (G.P.); bernadette.teleky@usamvcluj.ro (B.-E.T.) \\ 2 Department of Animal Production and Food Safety, University of Agricultural Sciences and Veterinary \\ Medicine, 400372 Cluj-Napoca, Romania; cristina.pocol@usamvcluj.ro \\ 3 Institute of Life Sciences, University of Agricultural Sciences and Veterinary Medicine, \\ 400372 Cluj-Napoca, Romania \\ * Correspondence: dan.vodnar@usamvcluj.ro; Tel.: +40-747-341-881
}

check for

updates

Citation: Precup, G.; Pocol, C.B.;

Teleky, B.-E.; Vodnar, D.C. Awareness, Knowledge, and Interest about Prebiotics-A Study among Romanian Consumers. Int. J. Environ. Res. Public Health 2022, 19, 1208 https://doi.org/10.3390/ ijerph19031208

Academic Editor: Paul B.

Tchounwou

Received: 16 December 2021

Accepted: 13 January 2022

Published: 21 January 2022

Publisher's Note: MDPI stays neutral with regard to jurisdictional claims in published maps and institutional affiliations.

Copyright: (C) 2022 by the authors. Licensee MDPI, Basel, Switzerland. This article is an open access article distributed under the terms and conditions of the Creative Commons Attribution (CC BY) license (https:// creativecommons.org/licenses/by/ $4.0 /)$.

\begin{abstract}
The consumer awareness towards healthier diets and the impact of nutrition on health has triggered an increase in the production and commercialization of foods with health claims. The scientific literature classifies these food products as functional foods, with a role in promoting health and preventing diseases, and they had a market share of almost 200 million EUR in 2019. Prebiotics are considered functional foods, referring to substrates that are selectively utilized by host microorganisms conferring a health benefit, as defined by the International Scientific Association for Probiotics and Prebiotics. Several health benefits are associated with the consumption of prebiotics; however, specific requirements must demonstrate the causality between the specific ingredient and the claimed effect. Health claims associated with food products are assessed in the European Union and need to be supported by rigorous scientific evidence before being authorized and permitted on the market. Consumers' perception of this topic is influenced by the various stakeholders involved. The current work aimed to study the consumers' perception and interest and to assess the knowledge on the prebiotic concept in Romania. The consumer interest level was quantified by using the web-based data tool Google Trends, and a questionnaire-based investigation was designed. The collected data were analyzed with the help of the SPSS program, and crosstabulation was used to identify the influence of socio-demographic characteristics on diet choice and awareness of prebiotics. A total of 303 persons answered the online applied questionnaire, grouped as young consumers (15-24 years old) and adults (25-64 years old). Even if most responders were familiar with the term of prebiotics ( $74 \%$ of total responders), some results were contradictory regarding their knowledge. The work emphasized the need to carry out educational campaigns and inform consumers on the relationship between certain food ingredients and health outcomes in a clear way and based on a rigorous assessment of the scientific evidence.
\end{abstract}

Keywords: consumer behavior; prebiotics; evidence; attitude; food; education

\section{Introduction}

In recent years, the shift of the consumer's behavior towards healthier diets and nutritious foods increased tremendously since researchers linked some food ingredients with potential health benefits [1-4]. The growing demand triggered an increase in the global market for functional foods, especially for the so-called "prebiotic" compounds and "probiotics" [1,4-6]. Recent studies associated the consumption of prebiotics with potential beneficial effects on human and animal health, namely on the gastrointestinal tract (GI), obesity, type 2 diabetes mellitus, irritable bowel syndrome and inflammatory bowel disease, cardiovascular diseases, bones, and neurological disorders, such as anxiety, depression, and cognitive deficiency [2,7-11]. While there is a general consumer perception that prebiotics 
impart beneficial effects, there is still a lack of knowledge in understanding the definition, while the mechanisms of effect and health attribute still need to be elucidated.

The concept of "prebiotics" was coined in 1995 by Gibson and Roberfroid, referring to a feeding ingredient resistant to digestion, fermentable in the colon ecosystem, and that is able to stimulate the growth and/or the activity of specific microorganisms from the gut, thus being beneficial in the intestinal physiology [1]. The increasing knowledge on the complexity of the gut microbiota and its interaction with the host expanded the concept and definition of prebiotics as a consequence of the advances in microbiome research and the advent of high-throughput sequencing techniques [10]. Therefore, the latest definition was given in 2018 by a panel of experts from the International Scientific Association for Probiotics and Prebiotics (ISAPP) as "a substrate that is selectively utilized by host microorganisms conferring a health benefit" [12].

In this regard, the body of evidence reporting the potential beneficial effects of some nutrients, such as inulin and oligofructose (produced from inulin) and fructooligosaccharides (FOS) synthetically produced from sucrose as well as galactose-containing and xylose-containing oligosaccharides (xylooligosaccharides), began to appear in the 1980s and early 1990s $[5,13,14]$. Japanese researchers were the first who discovered the value of non-digestible oligosaccharides. They showed that the intake of FOS and galactooligosaccharides (GOS) found in human milk stimulated the growth of intestinal bifidobacteria within the human gut $[13,14]$.

The interplay between prebiotics and probiotics as food or drug triggered the need for specific requirements to be classified as prebiotics as defined by ISAPP, a non-profit organization promoting probiotic and prebiotic science [12], whose definition is as follows: firstly, the ability to be resistant to gastric acidity, enzymes hydrolysis, and gastrointestinal absorption; selectively fermented by intestinal microorganisms; and selectively target and stimulate the growth and activity of gut bacteria $[1,12,15]$. In-vitro and in-vivo studies are needed to demonstrate a substrate's health benefit with potential prebiotic effects. In-vitro tests can be used to screen the potential candidates, and then, clinical trials are required to quantify the target bacteria and demonstrate the prebiotic effect. As highlighted by early research, the most common microorganisms shown to "selectively" utilize prebiotics were Bifidobacterium and Lactobacillus [16-19]. However, due to the limitations of culture methods, the evidence was insufficient to demonstrate the changes in the gut microbial ecosystem that could utilize the prebiotic substrates. Still, in the past decade, the highthroughput sequencing techniques revealed other autochthonous gut bacteria, including Faecalibacterium prausnitzii and Akkermansia muciniphila, that increased in abundance as a response to prebiotic intake $[9,20-22]$.

Furthermore, prebiotics and probiotics could be combined into "synbiotics" [23], so synergetic effects could be obtained, as the probiotic strain might be stimulated to grow by fermenting the prebiotic [6,24]. As of January 2022, there were 277 registered clinical trials (https: / / clinicaltrials.gov/ct2/results?term=prebiotics\&Search=Apply\&recrs= e\&age_v $=\& g n d r=\&$ type $=\& r s l t=$, accessed on 6 January 2022) worldwide, the majority in Europe, which evaluated the effect of prebiotics (alone or in combination with probiotics) on body weight and obesity metabolic syndrome, type 2 diabetes mellitus, gastrointestinal disorders (diarrhea, constipation, enterocolitis), irritable bowel syndrome and inflammatory bowel disease, and cardiovascular diseases but also on anxiety disorders, arthritis, or allergies [25-33]. The associated health outcomes of prebiotics in the GI tract highlighted in the literature were linked to the stimulation of immune system by inhibiting the potential for the growth of pathogenic microorganisms; production of short-chain fatty acids, such as acetate propionate and butyrate; lowering the intestinal $\mathrm{pH}$; and promoting mineral absorption.

However, in the European Union (EU), any health claim on food has to be substantiated by scientific evidence, requiring assessment by the European Food Safety Authority (EFSA) and authorization by the European Commission (EC). Food business operators must follow the provisions of the Regulation (EC) No. 1924/2006 when they want to label or advertise 
the particular beneficial effects of their products in relation to health and nutrition. To date, the only authorized health claim by EU as defined in Art. 13.5 from the regulation mentioned above refers to chicory inulin, which contributes to normal bowel function by increasing stool frequency at a daily intake of $12 \mathrm{~g}$ chicory inulin. Other compounds, such as GOS, XOS, isomalto-oligosaccharide, or sugar cane fiber, were authorized as novel food ingredients by the EC after a positive opinion by EFSA on their safety for human consumption for specific proposed uses [34-37] as prebiotic ingredients, sources, and for food applications.

The main prebiotic actors from the current body of evidence are the inulin-derived fructans (FOS, inulin, and oligofructose), derived from various crops, or sucrose and GOS, manufactured from lactose, a waste product of the dairy industry. The inulinderived fructans (FOS) are found in various vegetable species, such as onion, garlic, celery, asparagus, chicory roots, Jerusalem artichokes (topinambur), and yacon potato, but also in some grains and cereals, such as wheat and barley [29,30,38-40]. Human milk is another source of oligosaccharides (HMOs), which are structurally similar to GOS and are essential for newborn babies' metabolic and immunological systems [31]. However, most foods contain only trace levels of these nutrients; therefore, researchers have found alternatives to produce them by synthesis, enzymatic, thermal, or chemical processes [41].

Waste biomass from the agro-food industry, such as corn cobs and cereal by-products (wheat bran, straws, etc.), could represent a novel source for extracting compounds to be used for various food applications [42-44]. An example would be xylooligosaccharides (XOS), obtained from the hemicelluloses fraction of those waste materials [31]. Recent studies reported that polyphenols, polyunsaturated fatty acids (PUFAs), proteins, hydrolysates, and peptides might be potential candidates of prebiotic compounds [45].

Prebiotics were utilized in food applications, such as fermented milk/yogurts, breakfast cereals, sports or health drinks, energy bars, sugar-free candy, chewing gum, baked goods, meat products, pet foods, and feed or in food packaging [46-54]. However, there is no consensus on a daily intake of prebiotics regarding the dose until now.

Finally, since the outbreak of COVID-19, consumers' interest worldwide in prebiotics had an increasing curve, as observed by simply examining Google search trends on this specific term (Figure 1). It was noticed that the search interest reached the maximum popularity of the term in January 2020 compared to December 2019 and the whole of 2021. Additionally, the body of evidence investigating the role of prebiotics and probiotics in immunity during respiratory infections emerged [55].

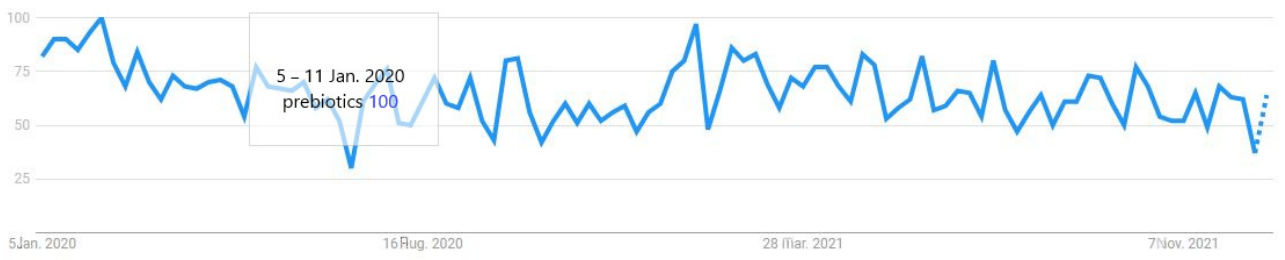

Figure 1. The level of interest in "prebiotics" from December 2019 to December 2021 (https:/ / trends. google.com/, accessed on 6 January 2022).

Considering the growing interest in these type of compounds, the present work aimed to investigate the current status of prebiotics research in Romania and explore the awareness and knowledge on this topic among Romanian consumers and how sociodemographic characteristics influence the behavior of consumers regarding dietary choices. The work could potentially help the interested stakeholders to address consumer needs and preferences regarding food applications with claimed effects. 


\section{Materials and Methods}

\subsection{Consumer Interest Level for Prebiotics in Romania}

To investigate and quantify the level of interest of consumers from Romania on prebiotics, the web-based data tool Google Trends was used, which became a very popular source for extensive data research and was demonstrated useful in assessing and predicting aspects of human behavior [56]. Google Trends offers data on the search volume for specific search terms in a "search volume index" (SVI) from 0-100, representing the relative search volume for a search term indexed against the overall search volume. Data are not given the actual volume and can be classified by category, time, and geographical location (worldwide, country, state, metropolitan region, and city). Peak search activity over a specific period is graded as $100 \%$, and search activity is presented relative to that peak at all other time points. We queried Google trends via the Google Insights for Search (http:/ / google.com/trends, accessed on 6 January 2022) using terminology related to prebiotics in Romanian from May 2018 to December 2021.

\subsection{Online Survey}

\subsubsection{Participants}

Participants living in Romania and Romanians settled abroad were asked to anonymously complete an online questionnaire about the knowledge, use, and perception of prebiotics, which was published on social media channels and distributed face-to-face among students from the University of Agricultural Sciences and Veterinary Medicine from Cluj-Napoca. Data were collected between May and July 2018. Participants were grouped as young consumers (15-24 years old) and adults (25-64 years old).

\subsubsection{Survey Design}

As a survey instrument, a brief, two-part questionnaire was designed. It consisted of 10 questions, with both close-ended and open-ended questions. The questionnaire's application duration ranged between 3 to $5 \mathrm{~min}$, and participants answered the Romanian version of the questionnaire.

\subsubsection{Questionnaire Instrument}

The questionnaire consisted of close-ended questions and included rating-scale questions (semantic differential), multiple-choice, dichotomous, and open-ended questions. Demographical information was required in the first part, such as gender, location, and education level [57]. The second part contained questions about the type of diet (mixed, semi-vegetarian, ovo-lacto-vegetarian, lacto-vegetarian, total vegetarian, or vegan) and consumption frequency of certain foods or food supplements, respectively, as follows: whole grains (e.g., wheat, barley, oats), wild rice, quinoa, soy, seeds (flax and pumpkin seeds), tomatoes, onions, leeks, garlic, asparagus, artichokes, ginger, radishes, carrots, bananas, berries, apples, dark chocolate, honey, and yogurt. The frequency of consumption of the foods mentioned above was investigated using a measurement scale, which included every day/almost daily, at least once a week, at least once a month, 1-2 times a year, never, or I do not know. Another question assessed their knowledge of the composition of the food mentioned above, which contained non-digestible food ingredients (dietary fiber) classified as prebiotics by the literature.

The respondents were further asked if they were aware of the concept of prebiotics, how they would appreciate their understanding of the concept from a scale from 1 to 10 (where 1 meant they did not know anything about it, and 10 meant they knew a great deal of information), and finally, what was the first thing that came into their mind when hearing this term. To assess their knowledge on the potential beneficial effects associated with prebiotic consumption, the respondents had a multiple choice question with the following options: "improve digestion", "support the immune system", "contribute to a better absorption of nutrients", "detoxify the body", "contribute to better stress management", or the option "I do not know/I do not answer." Finally, to assess the consumers' perception 
of the stakeholders responsible for carrying the educational campaigns for informing about the potential beneficial effects, respondents could choose between the family doctor, nutritionist/dietitian, pharmacist, researchers, mass media, family, school, or to mention other means of information.

\subsubsection{Statistical Analysis}

Data analysis was carried out using Statistical Package for the Social Sciences (SPSS) software program (SPSS Inc., Chicago, IL, USA). Descriptive statistics and crosstabulation were used to identify the influence of socio-demographic characteristics, such as gender, age, and education, on diet choice, prebiotics' perception, and knowledge. The data are reported as the mean \pm standard deviation (SD) $[58,59]$, and differences between means at the $5 \%$ level were considered statistically significant.

\section{Results}

\subsection{Consumer Interest Level}

The search trends for the term "prebiotic" in Romania, analyzed from May 2018 when the questionnaire was applied up to December 2021, had an interesting evolution over the four years. If in 2018 (May-December), the search volume index (SVI) was below 50, from 2019, it increased, with the highest peak (100) between April and May at a constant trend throughout the year. From January 2021, the trend increased from 0 to 75, which could probably be related to the COVID-19 pandemic. People are becoming more interested in foods that could help them maintain good health and improve immunity (Figure 2) [60-62]. However, the number of searches is not provided by the tool.

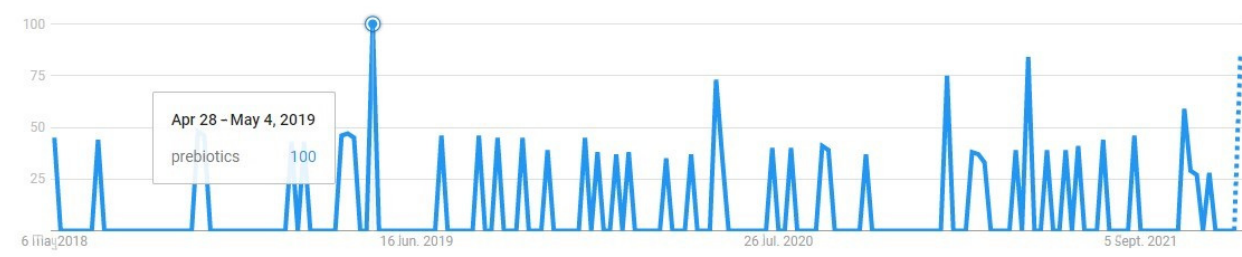

Figure 2. The level of interest in "prebiotics" from May 2018 to September 2021 (https://trends. google.com/, accessed on 6 January 2022).

\subsection{Demographics}

A total of 303 questionnaires were obtained through the online investigation, of which one was excluded due to incomplete data. A part of this subsample was extracted from a study made at a national level on 1506 students, conducted during 2017-2018 [63]. The respondents were grouped as young consumers (15-24 years old) and adults (25-64 years old). The young consumers represented $33 \%$ of total respondents, with an average age of 22 years old, while the adults represented almost $67 \%$ of total respondents and had an average of 33 years old. Male respondents represented $24.2 \%$ of the total participants, while women represented $75.8 \%$. Concerning the geographical location of the Romanian consumers, it was noticed that the majority of the respondents were from the county of Cluj (53\%), followed by the capital Bucharest (11\%) and the county Bistrita-Nasaud (5.3\%). A total of $21 \%$ of responders were spread in other counties, and Romanians living in other countries represented $6 \%$ of the total participants.

Concerning the educational level of respondents, the majority (75\%) was represented by participants with higher education (bachelor's degree, master's, and/or Ph.D. studies) (Figure 3). Demographic characteristics of the study participants are presented in Table 1. 
Table 1. Demographic characteristics of study participants.

\begin{tabular}{|c|c|c|}
\hline Demographics & $\mathbf{n}$ & $\%$ \\
\hline Young consumers (15-24 years old) & 101 & 33.4 \\
\hline Adults (25-64 years old) & 201 & 66.6 \\
\hline \multicolumn{3}{|l|}{ Gender } \\
\hline Male & 73 & 24 \\
\hline Female & 229 & 76 \\
\hline \multicolumn{3}{|l|}{ Geographical location (counties/abroad) } \\
\hline Alba & 4 & 1.3 \\
\hline Arad & 3 & 1 \\
\hline Arges & 1 & 0.3 \\
\hline Bacau & 1 & 0.3 \\
\hline Bihor & 7 & 2.3 \\
\hline Bistrita-Nasaud & 16 & 5.3 \\
\hline Botosani & 1 & 0.3 \\
\hline Brasov & 3 & 1 \\
\hline Bucuresti & 33 & 11 \\
\hline Buzau & 1 & 0.3 \\
\hline Caras-Severin & 1 & 0.3 \\
\hline Cluj & 160 & 53 \\
\hline Suceava & 4 & 1.3 \\
\hline Galati & 5 & 1.7 \\
\hline Harghita & 1 & 0.3 \\
\hline Hunedoara & 2 & 0.7 \\
\hline Iasi & 6 & 2 \\
\hline Maramures & 7 & 2.3 \\
\hline Mures & 3 & 1 \\
\hline Neamt & 2 & 0.7 \\
\hline Sibiu & 3 & 1 \\
\hline Ialomita & 2 & 0.7 \\
\hline Salaj & 3 & 1 \\
\hline Buzau & 1 & 0.3 \\
\hline Satu-Mare & 4 & 1.3 \\
\hline Timis & 7 & 2.3 \\
\hline Dambovita & 1 & 0.3 \\
\hline Vaslui & 1 & 0.3 \\
\hline Vrancea & 1 & 0.3 \\
\hline \multicolumn{3}{|l|}{ Abroad } \\
\hline France & 3 & 1 \\
\hline Germany & 5 & 1.7 \\
\hline Spain & 6 & 2 \\
\hline United Kingdom (UK) & 1 & 0.3 \\
\hline Ukraine & 1 & 0.3 \\
\hline Moldova & 2 & 0.7 \\
\hline
\end{tabular}

The results of the data analysis showed that the majority of respondents, $84.4 \%$, proclaimed having an omnivorous diet, including both plant and animal foods, of which the majority was represented by women $(73 \%)$, with a mean age of 30 years old.

Reduced percentages were recorded in the case of participants who adopted a semivegetarian diet (6.3\%), ovo-lacto-vegetarian (5\%), and lacto-vegetarian (1.3\%) (Figure 4 ). Vegans and vegetarians were poorly represented $(1.7 \%$ and $1 \%$, respectively). The association between type of diets and respondents' gender showed that approximately $81 \%$ of women and $95 \%$ of men had a mixed diet. A percentage of $19 \%$ of women with a mean age of 29 years old adopted a vegetarian diet (lacto-, ovo-, semi-vegetarian, vegan diet), while only $5 \%$ of men with a mean age of 31 years old were following this dietary lifestyle. Furthermore, the respondents were asked about the frequency (daily, at least once a week, at least once a month, 1-2 times a year, never, or the option I do not know/I do 
not answer) of consuming some foods that contain inulin-derived fructans (FOS) or other non-digestible compounds.

Education (last graduate school)

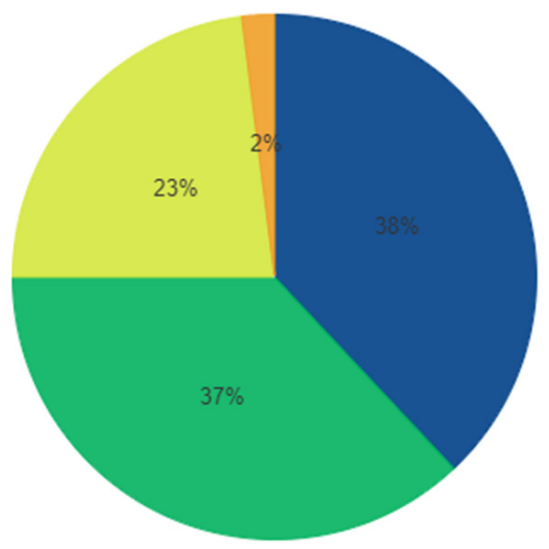

Higher education (license level)

Higher education (master's level, doctorate)

Highschool

Post-secondary school

Figure 3. The educational level of the responders.

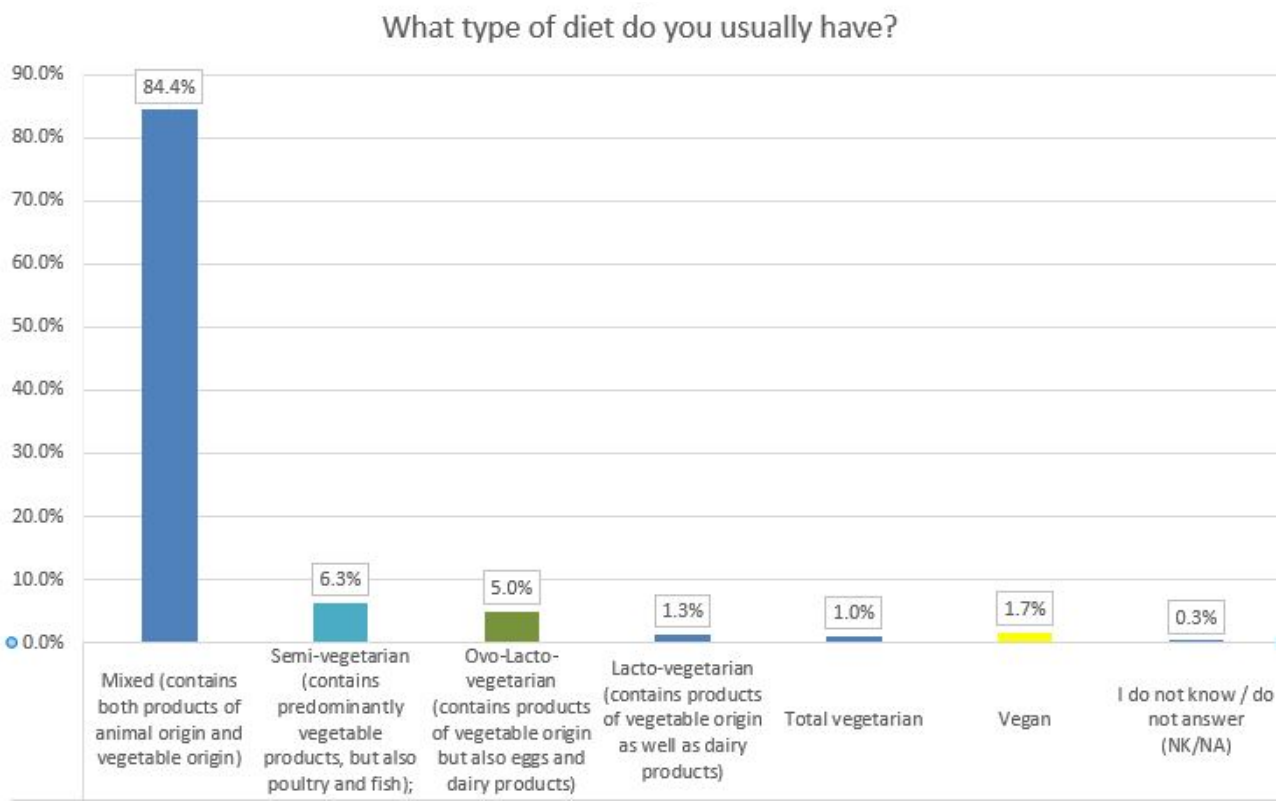

Figure 4. The type of diet reported by participants.

As observed in Table 2, tomatoes were consumed on a daily basis (around $57 \pm 0.9 \%$ of total responses), while onions $(45.03 \pm 1 \%)$, carrots $(52.7 \pm 0.9 \%)$, garlic $(51.66 \pm 0.9 \%)$, whole grains $(35.76 \pm 1.2 \%)$, bananas $(48.7 \pm 0.9 \%)$, apples $(40.1 \pm 0.9 \%)$, yogurt $(37.8 \pm 1.2 \%)$, and honey $(24.1 \pm 1.2 \%)$ are consumed more often once a week rather than daily. At the opposite pole, the food products consumed more rarely, around one to two times a year or never, were represented by artichokes $(87.1 \pm 0.9 \%)$, asparagus $(75.9 \pm 1 \%)$, quinoa $(75.6 \pm 0.9 \%)$, soy $(69.7 \pm 1 \%)$, leeks $(69.0 \pm 1 \%)$, or wild rice $(67.3 \pm 1.1 \%)$. Interestingly, the responders to the survey reported that food supplements were not popular in their diet (84\% taking supplements 1-2 times a year or never). However, no association was noticed between the educational level and dietary habits except in the vegetarian and vegan group, where most of the respondents had higher education (bachelor's, master's, 
Ph.D. studies) $(82.6 \pm 1.1 \%)$. In addition, no significant statistical differences were noticed between the frequency of consuming different food products and age groups (young and adults) $(p>0.5)$.

Table 2. Frequency of consumption of certain food products.

\begin{tabular}{|c|c|c|c|}
\hline \multirow[b]{2}{*}{ Food Products } & \multicolumn{3}{|c|}{ Responses (\%) } \\
\hline & $\begin{array}{c}\text { Every Day, Almost } \\
\text { Daily }\end{array}$ & $\begin{array}{c}\text { At Least Once a } \\
\text { Week }\end{array}$ & $\begin{array}{c}\text { 1-2 Times a Year or } \\
\text { Never }\end{array}$ \\
\hline Tomatoes & $56.8 \pm 0.9^{a}$ & $32.78 \pm 0.9^{b}$ & $2.65 \pm 0.9^{\mathrm{d}}$ \\
\hline Onion & $38.9 \pm 1^{b}$ & $45.03 \pm 1^{\mathrm{a}}$ & $3.9 \pm 1^{\mathrm{d}}$ \\
\hline Bananas & $28.1 \pm 0.8^{b, c}$ & $48.7 \pm 0.9^{a}$ & $2.98 \pm 0.9^{\mathrm{d}}$ \\
\hline Carrots & $23.8 \pm 0.8^{c}$ & $52.7 \pm 0.9^{a}$ & $2.32 \pm 0.9^{d}$ \\
\hline Honey & $22.8 \pm 1.2^{\mathrm{c}}$ & $24.1 \pm 1.2^{\mathrm{c}}$ & $19.5 \pm 1.2^{\mathrm{c}}$ \\
\hline Apples & $20.1 \pm 0.9^{c}$ & $40.1 \pm 0.9^{a, b}$ & $8.6 \pm 0.9^{d}$ \\
\hline Whole grains & $20.86 \pm 1.2^{c}$ & $35.76 \pm 1.2^{b}$ & $0.2 \pm 1.2^{\mathrm{d}}$ \\
\hline Garlic & $13.25 \pm 0.8^{\mathrm{c}, \mathrm{d}}$ & $51.66 \pm 0.9^{a}$ & $7.2 \pm 0.9^{\mathrm{d}}$ \\
\hline Berries & $12.6 \pm 1^{c, d}$ & $30.79 \pm 1^{b}$ & $19.2 \pm 0.3^{c}$ \\
\hline Artichokes & $0.6 \pm 0.8^{\mathrm{d}}$ & $1.3 \pm 0.8^{\mathrm{e}}$ & $87.1 \pm 0.9^{a}$ \\
\hline Asparagus & $1.9 \pm 1^{\mathrm{d}}$ & $4 \pm 1^{\mathrm{e}}$ & $75.9 \pm 1^{\mathrm{a}}$ \\
\hline Wild rice & 0 & $8.2 \pm 1^{\mathrm{d}}$ & $67.3 \pm 1.1^{b}$ \\
\hline Quinoa & 0 & $4.5 \pm 0.9^{\mathrm{e}}$ & $75.6 \pm 0.9^{\mathrm{a}}$ \\
\hline Soy & 0 & $5.3 \pm 1^{\mathrm{e}}$ & $69.7 \pm 1^{b}$ \\
\hline Leeks & $2.3 \pm 1^{d}$ & $7.2 \pm 1 \mathrm{~d}, \mathrm{e}$ & $69.0 \pm 1^{b}$ \\
\hline Chia seeds & $5.3 \pm 1.2^{\mathrm{d}}$ & $10.6 \pm 1.2^{\mathrm{d}}$ & $62.7 \pm 1.3^{b}$ \\
\hline Yogurt & $20.5 \pm 1.2^{\mathrm{c}}$ & $37.8 \pm 1.2^{b}$ & $13.2 \pm 1.2^{\mathrm{c}, \mathrm{d}}$ \\
\hline Food supplements & $0.05 \pm 1.2^{\mathrm{d}}$ & 0 & $84.2 \pm 1.2^{\mathrm{a}}$ \\
\hline
\end{tabular}

Results are displayed as mean values $\pm \mathrm{SD}, \mathrm{g} / \mathrm{L}, n=3$; in every column, the significant differences $(p<0.05)$ are displayed with different superscript letters (a-e) between the types of food products. Statistical Package for the Social Sciences (SPSS) software program (SPSS Inc., Chicago, IL, USA).

Moreover, more than half of the responders ( $53 \pm 0.53 \%)$ were not aware that the food products consumed (Table 2) contained non-digestible compounds that might stimulate the growth of intestinal lactic acid bacteria with potential health outcomes. When considering only respondents with higher education, women were more informed than men $(27 \pm 0.4 \%$ vs. $7 \pm 0.1 \%, p<0.5)$ on this aspect. However, no significant statistical difference $(p>0.5)$ was observed between women and men with higher education and respondents who graduated only high school and post-secondary school.

When assessing the awareness of respondents regarding the "prebiotic" concept, a percentage of $74 \%$ of the total respondents answered "yes," whereas $25 \%$ had not heard of it (Figure 5). Moreover, when considering only the answers provided by responders from the young group (15-24 years old), which represented 33\% of total responders, no significant statistical difference $(p>0.5)$ was observed between responders with higher education (bachelor's degree, master's, or Ph.D.) and those with high school and postsecondary school when assessing their awareness to the concept of "prebiotics." The adult group was represented by responders with a mean age of 30 years old, who were highly educated, and who knew about prebiotics in high number (more than $70 \pm 3 \%$ ). Since women were represented in higher percentages than men in this survey, no comparison was made between these groups. 


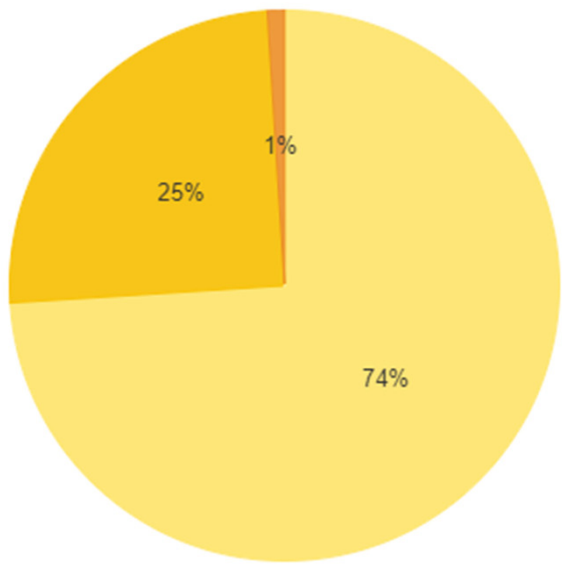

Figure 5. The awareness of the prebiotic concept.

When asked to assess their understanding about "prebiotics" on a scale from 1 to 10 , $22.4 \%$ of responders stated that they had no knowledge, while almost $6 \%$ had a great deal of knowledge. Moreover, we compared the responses of those who stated they heard about prebiotics with the self-assessment responses on this concept. We observed that $40 \pm 1 \%$ of those who were aware of it stated that they also understood the meaning (points from 6 to 10 on the rating scale), while $24 \pm 0.5 \%$ had not heard. They had little or no knowledge (points from 1 to 4 on the rating scale), and $20 \pm 0.5 \%$ knew about prebiotics, but they had little or no information. Interestingly, $1 \%$ of the responders stated that they had not heard the term "prebiotics" but had knowledge of it (points from 6 to 10 on the rating scale). In addition, some of the first words that would come in their mind when thinking about prebiotics were from different categories related to foods or health outcomes, including "functional foods", "garlic", "wheat bran", "yogurt", “onion”, "food supplements", "fibers", "digestion" "microbiota", "probiotics", "prevention", or "immunity" (Figure 6).
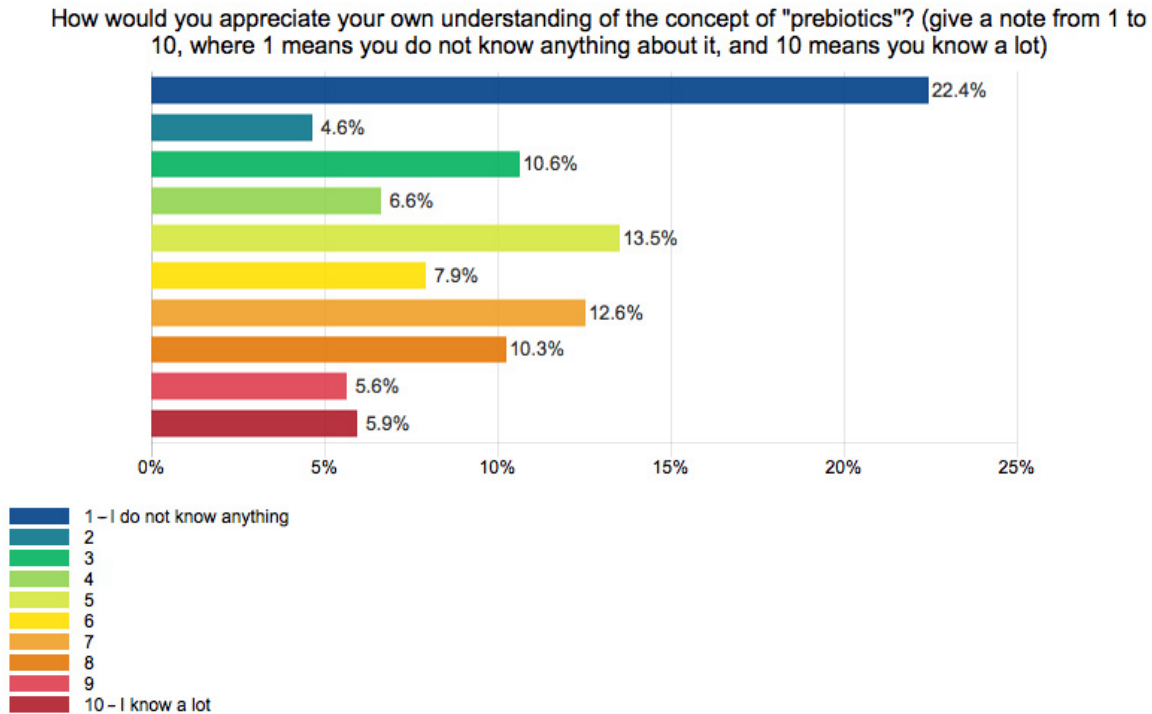

Figure 6. The self-assessment of prebiotic concept knowledge. 
Furthermore, $29.1 \%$ of respondents considered that the beneficial effects of consuming foods that contain compounds that might have prebiotic effects were improved digestion, followed by the claims of supporting the immune system $(21.3 \%)$, contributing to better absorption of nutrients $(16.8 \%)$, or detoxifying properties $(15.6 \%)$. Finally, the responders stated that they would consume foods containing potential prebiotic compounds more often if a better awareness existed (84.5\% of total respondents).

Finally, regarding the perception on the stakeholders responsible for consumers' information on prebiotics, the percentages were various: $36 \%$, considered that healthcare providers (family doctors, pharmacists, nutritionists, and dietitians) should be responsible of communicating, while $23 \%$ of participants would prefer to have this information from mass-media,18\% thought that the professors in schools should inform on such aspects, whereas $14 \%$ chose researchers and $8 \%$ their own families. (Figure 7 ).

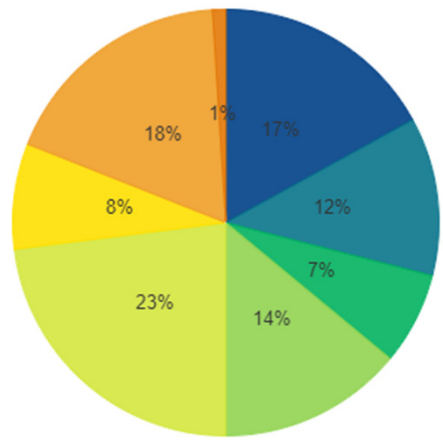

Family doctor

Figure 7. Perception on the stakeholders responsible for consumer's information on prebiotics.

\subsection{Research Status on Prebiotics in Romania}

In Romania, inulin was the most studied with respect to its prebiotic potential $[40,46,47,64]$. It has been used as an ingredient for obtaining functional foods, such as yogurt [46], bread [47], soy milk [48], and vegetable juices [49] (Figure 8). Prebiotic compounds have also been used as feed supplements for bees [50], pigs [51], or chickens [52]. Inulin and pectin were also used to encapsulate probiotic bacteria to test their behavior under gastrointestinal conditions $[53,54,65]$.

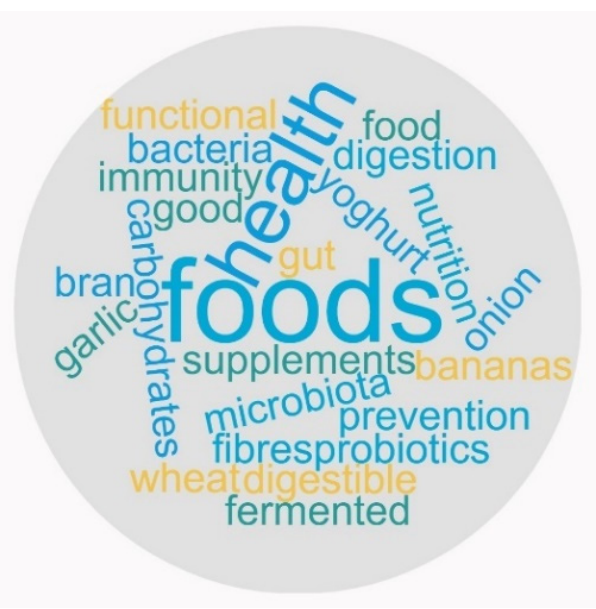

Figure 8. Terms associated with the concept of "prebiotics" by survey responders. 
Nevertheless, candidate or emerging prebiotics require additional evidence in humans before they can be fully established as prebiotic compounds [41].

\section{Discussion}

About $60 \%$ of the functional foods market nowadays focuses on digestive health, with prebiotics and probiotics probably occupying a high market share, as reported by the International Life Sciences Institute (ILSI) [12]. As a result, the prebiotic functional food market has emerged into a multi-million Euro industry, forecasted to register a CAGR of $12.2 \%$ until 2024 , fueled by the rising health awareness and shift in the consumer lifestyle. Moreover, as a result of continuing development and modernization in the direction of a thriving society, individuals are more inclined towards the functional food sector [66].

However, as reported by recent surveys, the general public's knowledge of prebiotics is limited [67-70]. In the USA, a survey from 2015 on 200 U.S. adults (patients at an urban hospital) reported that only $11 \%$ were familiar with the term "prebiotics." Only $7 \%$ identified the correct definition among four other choices. Moreover, the most-consumed food products with potential prebiotic compounds were yogurts (72\%) and cereals/granola bars (55\%). One of the reasons for consumption was the health-related benefits ("digestion or gut health"). Still, the most common reason was driven by curiosity of tasting or trying such foods ("to taste or try") [69]. The use of these types of ingredients in supplements is constantly increasing, reaching a frequency of $4.5 \%$ for pro-, $2.4 \%$ for pre-, and $1.1 \%$ for synbiotic products. Among consumers, the leading users were older people with higher earnings and educational levels [71,72].

Meanwhile, in Australia, almost 60\% [73] and in New Zealand, 25.4\% [74] of the interviewed adults had in the past or presently consumed probiotics. In both cases, the highest probiotic preponderance was generally observed among females, especially those with a higher education level. Conflicting results were found regarding the term prebiotic; although $42.8 \%$ of the persons who consumed probiotics knew this term, between nonconsumers, only $24.7 \%$ were familiar with it [73]. In general, adults who pursue healthier ways of life and have enhanced knowledge of gut health and the advantages of pre-, pro-, and synbiotic consumption are more likely to consume these ingredients $[75,76]$.

Another study conducted in India on college students highlighted that the primary source of information for them was from TV advertisements or social media. Still, the term prebiotics was not familiar among the same students except for a few of them [77]. Another survey targeting the perception and attitudes towards functional foods of young students from Turkey reported that more than half (59.7\%) of the respondents were not familiar with the functional food concept, and half of the participants might buy functional foods in the future if they would be more informed [67].

In Europe, a study conducted on 105 Slovak students to assess the knowledge on functional foods concluded that only a third of consumers were familiar with the concept, highlighting the need to raise awareness [78]. In Romania, a study conducted in 2016 on 265 consumers to evaluate the knowledge and attitude towards functional foods showed that consumers with high income were more interested in functional foods even if their understanding was not better than low-income consumers. In addition, the same study highlighted a high level of confusion regarding the definition of these types of foods [79].

Our work also emphasized that there is limited general knowledge on the prebiotic concept and that there is a need for better information that should be provided by healthcare providers regarding the association between food consumption and health outcomes. Even if most of the responders were familiar with the term (74\% of total responders), when assessing their knowledge, the results were contradictory (40\% understood the term, 24\% were not familiar and had little or no knowledge, and $20 \%$ were familiar but they had little or no information). Surprisingly, even healthcare providers have poor understanding of the prebiotic concept. For example, only $22 \%$ out of 256 registered dietitians, nurses, nurse practitioners, physicians, pharmacists, and physician assistants from a medical center in Chicago (USA) have heard of prebiotics. However, more than $83 \%$ would recommend 
prebiotics if proven by literature [70]. Confusion about the differences between probiotics and prebiotics was also common between healthcare providers in another study [80]. The scarce data from the scientific community on prebiotics could be responsible for the lack of knowledge of healthcare providers and highlights the importance of education in order to provide recommendations to patients.

The accelerated interest regarding the positive health effects given by the gut microbiota increased the scientific community's awareness and the public's attention regarding the consumption of prebiotic, probiotic, and synbiotic products [81-83]. A healthy gut relies on a balanced diet and healthy lifestyle [84] given by high fruit, vegetable, and fiber consumption; limited alcohol; and physical activities [77,79]. In addition, the current COVID-19 pandemic has highlighted the importance of a healthy gut microbiome and its attenuating effect on different respiratory infections $[85,86]$.

\section{Conclusions}

Our study emphasized that the population sample of Romanian consumers representing the young and adult population, mostly women $(76 \%)$ and highly educated (74\% completed or had ongoing bachelor's degree, master's, and/or Ph.D. studies), were in general familiar with the concept of prebiotics and some potential health outcomes shown by the scientific literature. However, we noticed scattered confusion among different groups regarding the concept's meaning. This could be due to the lack of a common consensus and terminology regarding this topic among the involved stakeholders, which leads to misinformation and confusion among consumers.

Future avenues of research should struggle more to confirm the causality between the health effects of emerging prebiotics and microbiota-mediated mechanisms so that healthcare providers can develop evidence-based recommendations. It is also of utmost importance to mention that food business operators who intend to commercialize food products with health claims in the EU should comply with the provisions of the Regulation (EC) No 1924/2006 when they want to label or advertise the particular beneficial effects of their products in relation to health and nutrition. Non-compliance with the Regulation will result in an unauthorized health claim when the claimed effect cannot be substantiated based on the scientific evidence.

Author Contributions: Conceptualization, G.P. and D.C.V.; methodology, C.B.P.; software, C.B.P.; validation, G.P. and D.C.V.; formal analysis, G.P. and D.C.V.; investigation, G.P., C.B.P. and D.C.V.; resources, D.C.V.; data curation, G.P., B.-E.T. and C.B.P.; writing-original draft preparation, G.P.; writing-review and editing, G.P., B.-E.T. and D.C.V.; visualization, G.P. and D.C.V.; supervision, D.C.V.; project administration, G.P. and D.C.V.; funding acquisition, D.C.V. All authors have read and agreed to the published version of the manuscript.

Funding: This research was funded by MCI-UEFISCDI, Grant Number TE 184, Project PN-III-P1-1.1TE-2019-1748, and by funds from the National Research Development Projects to finance excellence (PFE)-14/2022-2024 granted by the Romanian Ministry of Research and Innovation.

Institutional Review Board Statement: Not applicable.

Informed Consent Statement: Informed consent was obtained from all subjects involved in the study.

Data Availability Statement: The data presented in this study are available within the article. Other data that support the findings of this study are available upon request from the corresponding authors.

Acknowledgments: The authors would like to thank their Department of Food Science colleagues.

Conflicts of Interest: The authors declare no conflict of interest.

Disclaimer: The author Gabriela Precup is currently employed as Scientific Assistant by Randstad (c/o EFSA)'] and was employed as a trainee at the European Food Safety Authority (EFSA) between 1 November 2019 and 30 April 2021 in the Nutrition Unit that provides scientific and administrative support to the Panel on Nutrition, Novel Foods and Food Allergens in the area "Safety Assessment of Novel Foods". However, the present article is published under the sole responsibility of the authors 
Gabriela Precup, Cristina Bianca Pocol, Bernadette-Emőke Teleky and Dan Cristian Vodnar and may not be considered as an EFSA scientific output. The positions and opinions presented in this article are those of the author/s alone and are not intended to represent the views/any official position or scientific works of EFSA. To know about the views or scientific outputs of EFSA, please consult its website under http:/ / efsa.europa.eu (accessed on 16 December 2021).

\section{References}

1. Gibson, G.R.; Probert, H.M.; Van Loo, J.; Rastall, R.A.; Roberfroid, M.B. Dietary modulation of the human colonic microbiota: Updating the concept of prebiotics. Nutr. Res. Rev. 2004, 17, 259-275. [CrossRef]

2. Paiva, I.H.R.; Duarte-Silva, E.; Peixoto, C.A. The role of prebiotics in cognition, anxiety, and depression. Eur. Neuropsychopharmacol. 2020, 34, 1-18. [CrossRef] [PubMed]

3. De Paulo Farias, D.; de Araújo, F.F.; Neri-Numa, I.A.; Pastore, G.M. Prebiotics: Trends in food, health and technological applications. Trends Food Sci. Technol. 2019, 93, 23-35. [CrossRef]

4. Collins, S.; Reid, G. Distant site effects of ingested prebiotics. Nutrients 2016, 8, 523. [CrossRef] [PubMed]

5. Hidaka, H.; Tashiro, Y.; Eida, T. Proliferation of Bifidobacteria by Oligosaccharides and Their Useful Effect on Human Health. Bifidobact. Microflora 1991, 10, 65-79. [CrossRef]

6. Hutkins, R.W.; Krumbeck, J.A.; Bindels, L.B.; Cani, P.D.; Fahey, G., Jr.; Goh, Y.J.; Hamaker, B.; Martens, E.C.; Mills, D.A.; Rastal, R.A.; et al. Prebiotics-Why definitions matter. Curr. Opin. Biotechnol. 2016, 37, 1-7. [CrossRef] [PubMed]

7. Everard, A.; Lazarevic, V.; Derrien, M.; Girard, M.; Muccioli, G.M.; Neyrinck, A.M.; Possemiers, S.; Van Holle, A.; François, P.; De Vos, W.M.; et al. Responses of gut microbiota and glucose and lipid metabolism to prebiotics in genetic obese and diet-induced leptin-resistant mice. Diabetes 2011, 60, 2775-2786. [CrossRef]

8. Caramoci, A.; Vasilescu, M.; Nica, A.S.; Pop, M.; Rosulescu, E.; Ionescu, A.M. Potential pharmaceutical uses of probiotics and prebiotics in obesity management. Farmacia 2017, 65, 667-676.

9. Dewulf, E.M.; Cani, P.D.; Claus, S.P.; Fuentes, S.; Puylaert, P.G.B.; Neyrinck, A.M.; Bindels, L.B.; De Vos, W.M.; Gibson, G.R.; Thissen, J.P.; et al. Insight into the prebiotic concept: Lessons from an exploratory, double blind intervention study with inulin-type fructans in obese women. Gut 2013, 62, 1112-1121. [CrossRef]

10. Kellow, N.J.; Coughlan, M.T.; Reid, C.M. Metabolic benefits of dietary prebiotics in human subjects: A systematic review of randomised controlled trials. Br. J. Nutr. 2014, 111, 1147-1161. [CrossRef]

11. Călinoiu, L.F.; Vodnar, D.C. Whole Grains and Phenolic Acids: A Review on Bioactivity, Functionality, Health Benefits and Bioavailability. Nutrients 2018, 10, 1615. [CrossRef]

12. Gibson, G.R.; Hutkins, R.; Sanders, M.E.; Prescott, S.L.; Reimer, R.A.; Salminen, S.J.; Scott, K.; Stanton, C.; Swanson, K.S.; Cani, P.D.; et al. Expert consensus document: The International Scientific Association for Probiotics and Prebiotics (ISAPP) consensus statement on the definition and scope of prebiotics. Nat. Rev. Gastroenterol. Hepatol. 2017, 14, 491-502. [CrossRef]

13. Okazaki, M.; Fujikawa, S.; Matsumoto, N. Effect of Xylooligosaccharide on the Growth of Bifidobacteria. Bifidobact. Microflora 1990, 9, 77-86. [CrossRef]

14. Tanaka, R.; Takayama, H.; Morotomi, M.; Kuroshima, T.; Ueyama, S.; Matsumoto, K.; Kuroda, A.; Mutai, M. Effects of Administration of TOS and Bifidobacterium breve 4006 on the Human Fecal Flora. Bifidobact. Microflora 1983, 2, 17-24. [CrossRef]

15. Varvara, R.A.; Szabo, K.; Vodnar, D.C. 3D food printing: Principles of obtaining digitally-designed nourishment. Nutrients 2021, 13, 3617. [CrossRef] [PubMed]

16. Teleky, B.E.; Martău, A.G.; Ranga, F.; Chețan, F.; Vodnar, D.C.; Gheorghe, A.; Chet, F. Exploitation of lactic acid bacteria and Baker's yeast as single or multiple starter cultures of wheat flour dough enriched with soy flour. Biomolecules 2020, 10, 778. [CrossRef] [PubMed]

17. Szabo, K.; Teleky, B.-E.; Ranga, F.; Simon, E.; Pop, O.L.; Babalau-Fuss, V.; Kapsalis, N.; Vodnar, D.C. Bioaccessibility of microencapsulated carotenoids, recovered from tomato processing industrial by-products, using in vitro digestion model. LWT Food Sci. Technol. 2021, 152, 112285. [CrossRef]

18. Chen, J.; Vitetta, L. Modulation of gut microbiota for the prevention and treatment of Covid-19. J. Clin. Med. 2021, 10, 2903. [CrossRef]

19. Mitrea, L.; Călinoiu, L.-F.; Precup, G.; Bindea, M.; Rusu, B.; Trif, M.; Ferenczi, L.-J.; Ştefănescu, B.-E.; Vodnar, D.C. Inhibitory Potential of Lactobacillus Plantarum on Escherichia Coli. Bull. Univ. Agric. Sci. Vet. Med. Cluj-Napoca Food Sci. Technol. 2017, 74, 99. [CrossRef]

20. Cecchini, D.A.; Laville, E.; Laguerre, S.; Robe, P.; Leclerc, M.; Dore, J.; Henrissat, B.; Remaud-Simeon, M.; Monsan, P.; PotockiVeronese, G. Functional Metagenomics Reveals Novel Pathways of Prebiotic Breakdown by Human Gut Bacteria. PLoS ONE 2013, 8, e72766. [CrossRef]

21. Goh, Y.J.; Klaenhammer, T.R. Genetic mechanisms of prebiotic oligosaccharide metabolism in probiotic microbes. Annu. Rev. Food Sci. Technol. 2015, 6, 137-156. [CrossRef]

22. Mitrea, L.; Călinoiu, L.-F.; Precup, G.; Bindea, M.; Rusu, B.; Trif, M.; Ştefănescu, B.-E.; Pop, I.-D.; Vodnar, D.-C. Isolated microorganisms for bioconversion of biodiesel-derived glycerol into 1,3-Propanediol. Bull. UASVM Food Sci. Technol. 2017, 74, 43-49. [CrossRef] 
23. Simon, E.; Călinoiu, L.F.; Mitrea, L.; Vodnar, D.C. Probiotics, prebiotics, and synbiotics: Implications and beneficial effects against irritable bowel syndrome. Nutrients 2021, 13, 2112. [CrossRef] [PubMed]

24. Helmyati, S.; Shanti, K.M.; Sari, F.T.; Sari, M.P.; Atmaka, D.R.; Pratama, R.A.; Wigati, M.; Wisnusanti, S.U.; Nisa', F.Z.; Rahayu, E.S Synbiotic fermented milk with double fortification (Fe-zn) as a strategy to address stunting: A randomized controlled trial among children under five in yogyakarta, indonesia. Processes 2021, 9, 543. [CrossRef]

25. Beserra, B.T.S.; Fernandes, R.; do Rosario, V.A.; Mocellin, M.C.; Kuntz, M.G.F.; Trindade, E.B.S.M. A systematic review and meta-analysis of the prebiotics and synbiotics effects on glycaemia, insulin concentrations and lipid parameters in adult patients with overweight or obesity. Clin. Nutr. 2015, 34, 845-858. [CrossRef] [PubMed]

26. Nicolucci, A.C.; Reimer, R.A. Prebiotics as a modulator of gut microbiota in paediatric obesity. Pediatr. Obes. 2017, 12, 265-273. [CrossRef]

27. Parnell, J.A.; Raman, M.; Rioux, K.P.; Reimer, R.A. The potential role of prebiotic fibre for treatment and management of non-alcoholic fatty liver disease and associated obesity and insulin resistance. Liver Int. 2012, 32, 701-711. [CrossRef]

28. Cuello-Garcia, C.A.; Fiocchi, A.; Pawankar, R.; Yepes-Nuñez, J.J.; Morgano, G.P.; Zhang, Y.; Ahn, K.; Al-Hammadi, S.; Agarwal, A.; Gandhi, S.; et al. World Allergy Organization-McMaster University Guidelines for Allergic Disease Prevention (GLAD-P): Prebiotics. World Allergy Organ. J. 2016, 9, 10. [CrossRef]

29. Silk, D.B.A.; Davis, A.; Vulevic, J.; Tzortzis, G.; Gibson, G.R. Clinical trial: The effects of a trans-galactooligosaccharide prebiotic on faecal microbiota and symptoms in irritable bowel syndrome. Aliment. Pharmacol. Ther. 2009, 29, 508-518. [CrossRef]

30. Rolim, P.M. Development of prebiotic food products and health benefits. Food Sci. Technol. 2015, 35, 3-10. [CrossRef]

31. Rajendran, S.R.C.K.; Okolie, C.L.; Udenigwe, C.C.; Mason, B. Structural features underlying prebiotic activity of conventional and potential prebiotic oligosaccharides in food and health. J. Food Biochem. 2017, 41, e12389. [CrossRef]

32. Lamsal, B.P. Production, health aspects and potential food uses of dairy prebiotic galactooligosaccharides. J. Sci. Food Agric. 2012, 92, 2020-2028. [CrossRef]

33. Canfora, E.E.; Jocken, J.W.; Blaak, E.E. Short-chain fatty acids in control of body weight and insulin sensitivity. Nat. Rev. Endocrinol. 2015, 11, 577-591. [CrossRef]

34. EFSA Panel on Dietetic Products, Nutrition and Allergies (NDA). Scientific Opinion on the substantiation of a health claim related to "native chicory inulin" and maintenance of normal defecation by increasing stool frequency pursuant to Article 13.5 of Regulation (EC) No 1924/2006. EFSA J. 2015, 13, 3951. [CrossRef]

35. EFSA Panel on Dietetic Products, Nutrition and Allergies (NDA). Guidance on the scientific requirements for health claims related to the immune system, the gastrointestinal tract and defence against pathogenic microorganisms. EFSA J. 2016, 14, 4369. [CrossRef]

36. Ververis, E.; Ackerl, R.; Azzollini, D.; Colombo, P.A.; de Sesmaisons, A.; Dumas, C.; Fernandez-Dumont, A.; Ferreira da Costa, L.; Germini, A.; Goumperis, T.; et al. Novel foods in the European Union: Scientific requirements and challenges of the risk assessment process by the European Food Safety Authority. Food Res. Int. 2020, 137, 109515. [CrossRef]

37. Turck, D.; Bohn, T.; Castenmiller, J.; De Henauw, S.; Hirsch-Ernst, K.I.; Maciuk, A.; Mangelsdorf, I.; McArdle, H.J.; Naska, A.; Pelaez, C.; et al. Safety of the extension of use of galacto-oligosaccharides as a Novel food pursuant to Regulation (EU) $2015 / 2283$. EFSA J. 2021, 19, e06844. [CrossRef] [PubMed]

38. Liu, L.; Ren, J.; Zhang, Y.; Liu, X.; Ouyang, J. Simultaneously separation of xylo-oligosaccharide and lignosulfonate from wheat straw magnesium bisulfite pretreatment spent liquor using ion exchange resin. Bioresour. Technol. 2018, 249, 189-195. [CrossRef] [PubMed]

39. Beitane, I.; Ciprovica, I. The study of added prebiotics on b group vitamins concentration during milk fermentation. Rom. Biotechnol. Lett. 2011, 16, 92-96.

40. Dobre, T.; Parvulescu, O.C.; Stoica, A.; Stroescu, M. Experimental investigation and modelling of inulin and glycyrrhizin extraction. Rev. Chim. 2010, 61, 82-86.

41. Lelia, P.O.; Suharoschi, R. Emerging Food Processing Technologies: Probiotics and Prebiotics. In Nutraceutical and Functional Food Components; Academic Press: Cambridge, MA, USA, 2022; pp. 509-536. [CrossRef]

42. Precup, G.; Mitrea, L.; Nemes, A.; Călinoiu, L.-F.; Martău, G.-A.; Teleky, B.E.; Coman, V.; Vodnar, D.C. Food processing by-products and molecular gastronomy. In Gastronomy and Food Science; Academic Press: Cambridge, MA, USA, 2021; pp. 137-164.

43. Teleky, B.-E.; Martău, G.-A.; Vodnar, D.-C. Physicochemical Effects of Lactobacillus plantarum and Lactobacillus casei Cocultures on Soy-Wheat Flour Dough Fermentation. Foods 2020, 9, 1894. [CrossRef]

44. Martău, G.A.; Coman, V.; Vodnar, D.C. Recent advances in the biotechnological production of erythritol and mannitol. Crit. Rev. Biotechnol. 2020, 40, 608-622. [CrossRef] [PubMed]

45. Zhang, C.; Zhang, Y.; Li, H.; Liu, X. The potential of proteins, hydrolysates and peptides as growth factors for Lactobacillus and Bifidobacterium: Current research and future perspectives. Food Funct. 2020, 11, 1946-1957. [CrossRef] [PubMed]

46. Jimborean, M.; Ţibulcă, D.; Rotar, A.M.; Pop, C.; Socaci, S. Studies on Functional Yogurt with Added Inulin as Prebiotic Fiber. Bull. Univ. Agric. Sci. Vet. Med. Cluj-Napoca Food Sci. Technol. 2015, 72, 285-286. [CrossRef]

47. Sirbu, A.; Arghire, C. Functional bread: Effect of inulin-type products addition on dough rheology and bread quality. J. Cereal Sci. 2017, 75, 220-227. [CrossRef]

48. Iancu, C.; Barbu, V.; Nicolau, A.; Iordachescu, G. Attempts To Obtain a New Symbiotic Product Based on Soy Milk. Innov. Rom. Food Biotechnol. 2010, 7, 54855245. 
49. Buruleanu, L.; Manea, I.; Bratu, M.G.; Avram, D. Effects of prebiotics on the quality of lactic acid fermented vegetable juices. Ovidius Univ. Ann. Chem. 2009, 20, 102-107.

50. Pătruică, S.; Dumitrescu, G.; Stancu, A.; Bura, M.; Dunea, I.B. The Effect of Prebiotic and Probiotic Feed Supplementation on the Wax Glands of Worker Bees (Apis Mellifera). Sci. Pap. Anim. Sci. Biotechnol. 2012, 45, 45.

51. Şara, A.; Bentea, M.; Gabor, E.; Ani, A. (Toma) Influence of the ACTIGENTM Prebiotic on Productive Performances and Health in Pigs. Bull. Univ. Agric. Sci. Vet. Med. Cluj-Napoca Anim. Sci. Biotechnol. 2012, 69, 341-342. [CrossRef]

52. Ghasemi, R.; Sedghi, M.; Mahdavi, A.H. Evaluation of probiotic, prebiotic, and synbiotic on performance, immune responses, and gastrointestinal health of broiler chickens. Poult. Sci. J. 2020, 8, 175-188. [CrossRef]

53. Calinoiu, L.F.; Ştefanescu, B.E.; Pop, I.D.; Muntean, L.; Vodnar, D.C.; Călinoiu, L.-F.; Ştefănescu, B.; Pop, I.D.; Muntean, L.; Vodnar, D.C. Chitosan Coating Applications in Probiotic Microencapsulation. Coatings 2019, 9, 194. [CrossRef]

54. Pop, O.L.; Vodnar, D.C.; Suharoschi, R.; Mudura, E.; Socaciu, C.L. plantarum ATCC 8014 Entrapment with Prebiotics and Lucerne Green Juice and Their Behavior in Simulated Gastrointestinal Conditions. J. Food Process. Eng. 2016, 39, 433-441. [CrossRef]

55. Vodnar, D.-C.; Mitrea, L.; Teleky, B.-E.; Szabo, K.; Calinoiu, L.-F.; Nemes, S.-A.; Martău, G.-A. Coronavirus Disease (COVID-19) Caused by (SARS-CoV-2) Infections: A Real Challenge for Human Gut Microbiota. Front. Cell. Infect. Microbiol. 2020, 10, 575559. [CrossRef]

56. Mavragani, A.; Ochoa, G.; Tsagarakis, K.P. Assessing the methods, tools, and statistical approaches in Google trends research: Systematic review. J. Med. Internet Res. 2018, 20, e270. [CrossRef] [PubMed]

57. Newens, K.J.; Walton, J. A review of sugar consumption from nationally representative dietary surveys across the world. J. Hum. Nutr. Diet. 2016, 29, 225-240. [CrossRef] [PubMed]

58. Mitrea, L.; Teleky, B.-E.; Leopold, L.-F.; Nemes, S.-A.; Plamada, D.; Dulf, F.V.; Pop, I.-D.; Vodnar, D.C. The physicochemical properties of five vegetable oils exposed at high temperature for a short-time-interval. J. Food Compos. Anal. $2022,106,104305$. [CrossRef]

59. Mitrea, L.; Vodnar, D.C. Klebsiella pneumoniae-A useful pathogenic strain for biotechnological purposes: Diols biosynthesis under controlled and uncontrolled pH levels. Pathogens 2019, 8, 293. [CrossRef]

60. Pascuta, M.S.; Vodnar, D.C. Nanocarriers for sustainable active packaging: An overview during and post COVID-19. Coatings 2022, 12, 102. [CrossRef]

61. Olaimat, A.N.; Aolymat, I.; Al-Holy, M.; Ayyash, M.; Abu Ghoush, M.; Al-Nabulsi, A.A.; Osaili, T.; Apostolopoulos, V.; Liu, S.Q.; Shah, N.P. The potential application of probiotics and prebiotics for the prevention and treatment of COVID-19. NPJ Sci. Food 2020, 4, 17. [CrossRef]

62. Călinoiu, L.-F.F.; Cătoi, A.F.; Vodnar, D.C.; Catoi, A.-F.; Vodnar, D.C. Solid-state yeast fermented wheat and oat bran as a route for delivery of antioxidants. Antioxidants 2019, 8, 372. [CrossRef]

63. Pocol, C.B.; Marinescu, V.; Amuza, A.; Cadar, R.L.; Rodideal, A.A. Sustainable vs. unsustainable food consumption behaviour: A study among students from Romania, Bulgaria, and Moldova. Sustainability 2020, 12, 4699. [CrossRef]

64. Martău, G.A.; Teleky, B.-E.; Ranga, F.; Pop, I.D.; Vodnar, D.C. Apple pomace as a sustainable substrate in sourdough fermentation. Front. Microbiol. 2021, 12, 1-16. [CrossRef] [PubMed]

65. Teleky, B.-E.; Vodnar, D.C. Recent Advances in Biotechnological Itaconic Acid Production, and Application for a Sustainable Approach. Polymers 2021, 13, 3574. [CrossRef] [PubMed]

66. Granato, D.; Barba, F.J.; Bursać Kovačević, D.; Lorenzo, J.M.; Cruz, A.G.; Putnik, P. Functional Foods: Product Development, Technological Trends, Efficacy Testing, and Safety. Annu. Rev. Food Sci. Technol. 2020, 11, 93-118. [CrossRef]

67. Bilgiç, S.; Yüksel, A. University Students' Perception and Attitudes towards Functional Foods in Istanbul. In Proceedings of the 2012 International Conference on Industrial Engineering and Operations Management, Istanbul, Turkey, 3-6 July 2012.

68. Broers, V.J.V.; Van Den Broucke, S.; Luminet, O. Determinants of prebiotic vegetable consumption: The extended theory of planned behaviour. Arch. Public Health 2020, 78, 27. [CrossRef]

69. Betz, M.; Uzueta, A.; Rasmussen, H.; Gregoire, M.; Vanderwall, C.; Witowich, G. Knowledge, use and perceptions of probiotics and prebiotics in hospitalised patients. Nutr. Diet. 2015, 72, 261-266. [CrossRef]

70. Oliver, L.; Rasmussen, H.; Gregoire, M.B.; Chen, Y. Health care provider's knowledge, perceptions, and use of probiotics and prebiotics. Top. Clin. Nutr. 2014, 29, 139-149. [CrossRef]

71. O'Connor, L.E.; Gahche, J.J.; Herrick, K.A.; Davis, C.D.; Potischman, N.; Vargas, A.J. Nonfood Prebiotic, Probiotic, and Synbiotic Use Has Increased in US Adults and Children From 1999 to 2018. Gastroenterology 2021, 161, 476-486. [CrossRef]

72. Guarner, F.; Khan, A.G.; Garisch, J.; Eliakim, R.; Gangl, A.; Thomson, A.; Krabshuis, J.; Lemair, T.; Kaufmann, P.; de Paula, J.A.; et al. World gastroenterology organisation global guidelines: Probiotics and prebiotics october $2011 . \quad J$. Clin. Gastroenterol. 2012, 46, 468-481. [CrossRef]

73. Khalesi, S.; Vandelanotte, C.; Thwaite, T.; Russell, A.M.T.; Dawson, D.; Williams, S.L. Awareness and Attitudes of Gut Health, Probiotics and Prebiotics in Australian Adults. J. Diet. Suppl. 2021, 18, 418-432. [CrossRef] [PubMed]

74. Schultz, M.; Baranchi, A.; Thurston, L.; Yu, Y.C.; Wang, L.; Chen, J.; Sapsford, M.; Chung, J.; Binsadiq, M.; Craig, L.; et al. Consumer demographics and expectations of probiotic therapy in New Zealand: Results of a large telephone survey. N. Z. Med. J. 2011, 124, 36-43. [CrossRef]

75. Tanemura, N.; Hamadate, N. Association between consumers' food selection and differences in food labeling regarding efficacy health information: Food selection based on differences in labeling. Food Control 2022, 131, 108413. [CrossRef] 
76. Sharma, S.; Singh, A.; Sharma, S.; Kant, A.; Sevda, S.; Taherzadeh, M.J.; Garlapati, V.K. Functional foods as a formulation ingredients in beverages: Technological advancements and constraints. Bioengineered 2021, 12, 11055-11075. [CrossRef]

77. Bressa, C.; Bailén-Andrino, M.; Pérez-Santiago, J.; González-Soltero, R.; Pérez, M.; Montalvo-Lominchar, M.G.; Maté-Muñoz, J.L.; Domínguez, R.; Moreno, D.; Larrosa, M. Differences in gut microbiota profile between women with active lifestyle and sedentary women. PLoS ONE 2017, 12, e0171352. [CrossRef]

78. Jarossova, M.A. Knowledge of Slovak consumers about functional foods-Preliminary study. Towarozn. Probl. JAKOŚCI 2016, $2,12-17$.

79. Precup, G.; Vodnar, D.C. Gut Prevotella as a possible biomarker of diet and its eubiotic versus dysbiotic roles: A comprehensive literature review. Br. J. Nutr. 2019, 122, 131-140. [CrossRef]

80. Plamada, D.; Vodnar, D.C. Polyphenols-Gut Microbiota Interrelationship: A Transition to a New Generation of Prebiotics. Nutrients 2022, 14, 137. [CrossRef] [PubMed]

81. Guzel-Seydim, Z.B.; Gökırmaklı, Ç.; Greene, A.K. A comparison of milk kefir and water kefir: Physical, chemical, microbiological and functional properties. Trends Food Sci. Technol. 2021, 113, 42-53. [CrossRef]

82. Mărgăoan, R.; Stranț, M.; Varadi, A.; Topal, E.; Yücel, B.; Cornea-Cipcigan, M.; Campos, M.G.; Vodnar, D.C. Bee collected pollen and bee bread: Bioactive constituents and health benefits. Antioxidants 2019, 8, 568. [CrossRef]

83. Vodnar, D.C.; Socaciu, C. Green tea increases the survival yield of Bifidobacteria in simulated gastrointestinal environment and during refrigerated conditions. Chem. Cent. J. 2012, 6, 1-8. [CrossRef] [PubMed]

84. Vodnar, D.C.; Calinoiu, L.-F.; Mitrea, L.; Precup, G.; Bindea, M.; Pacurar, A.M.; Szabo, K.; Stefanescu, B.E. A new generation of probiotic functional beverages using bioactive compounds from agro-industrial waste. In Functional and Medicinal Beverages; Academic Press: Cambridge, MA, USA, 2019; Volume 11, pp. 483-528, ISBN 9780128163979.

85. Walton, G.E.; Gibson, G.R.; Hunter, K.A. Mechanisms linking the human gut microbiome to prophylactic and treatment strategies for COVID-19. Br. J. Nutr. 2021, 126, 219-227. [CrossRef] [PubMed]

86. Shinde, T.; Hansbro, P.M.; Sohal, S.S.; Dingle, P.; Eri, R.; Stanley, R. Microbiota modulating nutritional approaches to countering the effects of viral respiratory infections including SARS-CoV-2 through promoting metabolic and immune fitness with probiotics and plant bioactives. Microorganisms 2020, 8, 921. [CrossRef] [PubMed] 